SAINS TANAH - Journal of Soil Science and Agroclimatology

Journal homepage: http://jurnal.uns.ac.id/tanah

\title{
The kinetics curve of nitrogen mineralization from perennial leaves litter decomposed by earthworm (Phretima californica)
}

\author{
Kartika Utami ${ }^{1}$, Eko Hanudin ${ }^{2 *}$, Makruf Nurudin ${ }^{2}$ \\ ${ }^{1}$ Master Program of Soil Science Dept., Faculty of Agriculture, Universitas Gadjah Mada, Yogyakarta, Indonesia \\ ${ }^{2}$ Department of Soil Science, Faculty of Agriculture, Universitas Gadjah Mada, Yogyakarta, Indonesia
}

\begin{tabular}{|c|c|}
\hline ARTICLE INFO & ABSTRACT \\
\hline $\begin{array}{l}\text { Keywords: } \\
\text { Decomposition } \\
\mathrm{NH}_{4}{ }^{-} \\
\mathrm{NO}_{3}{ }^{-} \\
\mathrm{N} \text { release } \\
\text { Kinetics order } \\
\text { Article history } \\
\text { Submitted: 2019-12-24 } \\
\text { Accepted: 2020-12-28 } \\
\text { * Corresponding Author } \\
\text { Email address: } \\
\text { ekohanudin@ugm.ac.id }\end{array}$ & 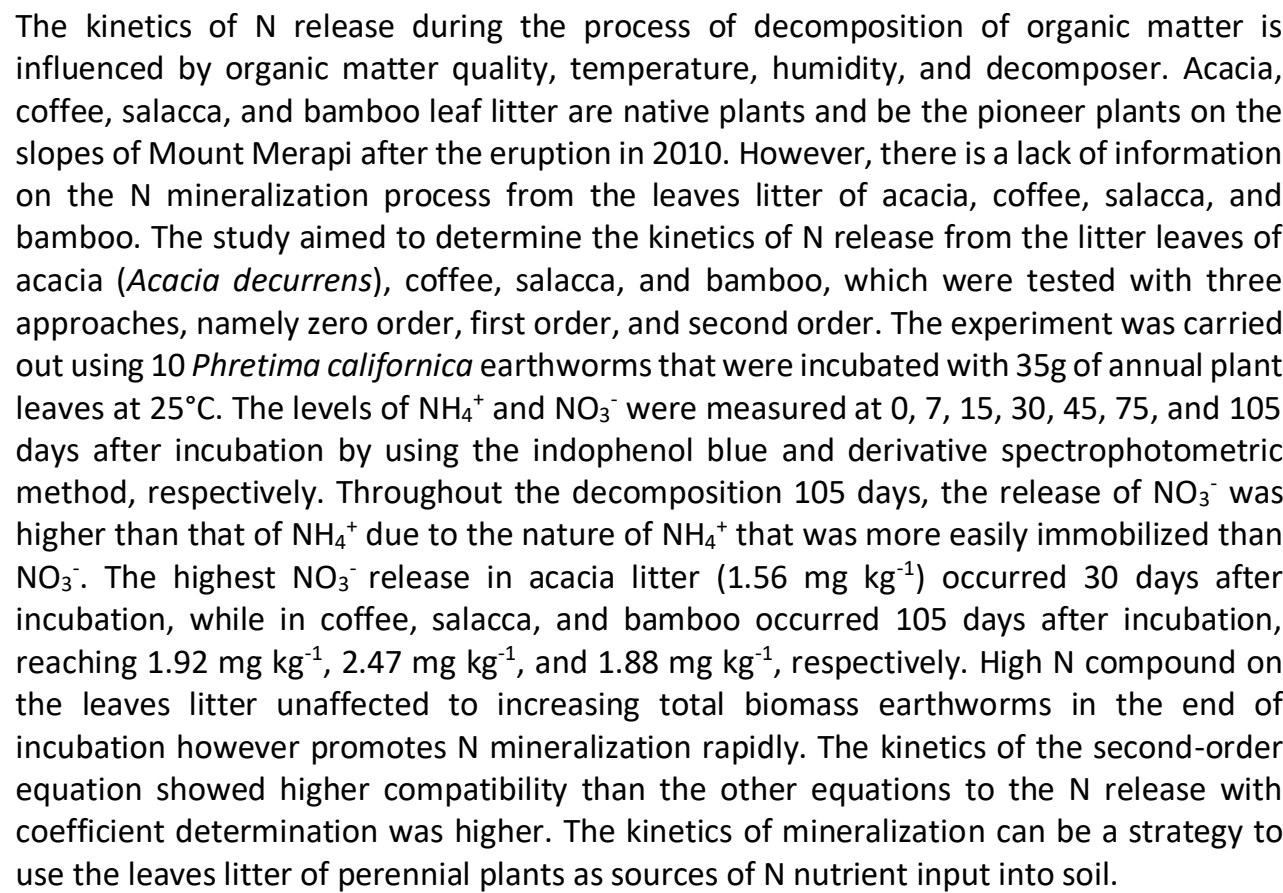 \\
\hline
\end{tabular}

How to Cite: Utami, K., Hanudin, E., and Nurudin, N. (2020). The kinetics curve of nitrogen mineralization from perennial leaves litter decomposed by earthworm (Phretima californica). Sains Tanah Journal of Soil Science and Agroclimatology, 17(2): 152-160 (DOI: 10.20961/stjssa.v17i2.46928)

\section{Introduction}

Litter decomposition plays an important role as the source of $\mathrm{N}$ in maintaining fertility and biological activities in the soil (Parton et al, 2007). N changes are affected by the initial chemical composition of organic matter (Manzoni et al, 2008) and its properties that are easily lost through leaching, evaporation, erosion, and absorption by plants (Patti et al, 2013). There have been some studies conducted to increase the availability of $\mathrm{N}$ through the mineralization process, one of which is the study by Bhat et al. (2018), reporting the measurement of $\mathrm{N}$ mineralization in 5 different types of soil with organic and inorganic fertilizers, where $\mathrm{N}$ mineralization potential and cumulative $\mathrm{N}$ mineralized is higher in soil receiving organic manures while the $\mathrm{N}$ mineralization rate is highest in the soil where the use of integrated nutrient management. Besides, Hasegawa \& Horie (1994) also determined an equation model to estimate $\mathrm{N}$ in paddy fields through differences in the percentage of moisture and soil temperature before submergence.

The mineralization pattern introduced by Stanford \& Smith (1972) illustrates the kinetic equation that consists of a simple model as a function of temperature and humidity. The model is based on three kinetic parameters, including potential mineralization $\left(\mathrm{N}_{0}\right)$, mineralization rate constant $(\mathrm{k})$, and activation energy $\left(E_{a}\right)$. Based on his experiments, almost 
all types of soil show that the net $\mathrm{N}$ mineralization is linearly the square root of time $\left(\mathrm{t}^{1 / 2}\right)$. Lodhi et al (2009) also add that net $\mathrm{N}$ mineralization increases with the increasing time, temperature, and humidity. Purwanto et al. (2005) state that the rate of $\mathrm{N}$ mineralization (positive or negative) depends on the balance of consumption and production of inorganic $\mathrm{N}$ itself.

Earthworms contribute to the process of decomposition through fragmentation, incorporation, and the mixing of plant residues into the soil (Jiang et al., 2018). Dechaine et al. (2005) added that earthworms had a positive correlation with the rate of litter decomposition. Besides, Lubbers et al. (2017) also proved that earthworms accelerated the mineralization of organic matter through $\mathrm{CO}_{2}$ and $\mathrm{N}_{2} \mathrm{O}$ gas loss from residual soybean plants by $112 \%$ and $670 \%$, respectively (Kernecker et al., 2014).

The quality of litter determines the rate of decomposition, as is the regulation of $\mathrm{N}$ mineralization (Pei et al., 2019). Acacia, coffee, salacca, and bamboo leaf litter are native plants and be the pioneer plants on the slopes of Mount Merapi after the eruption in 2010. However, there is a lack of information on the $\mathrm{N}$ mineralization process from the leaves litter of acacia, coffee, salacca, and bamboo. This study aimed to determine the kinetics of $\mathrm{N}$ mineralization from the four perennial leaves litter incubated with earthworm Phretima californica.

\section{Materials and Method}

\subsection{Preparation of soil, earthworm, and perennial plant leaves litter}

The soil used in the experiment was taken from the Kalitengah Lor area, which was located on the upper slope of Mount Merapi, Yogyakarta, Indonesia. The soil and leaves litter preparation was done by following the procedures of Jiang et al. (2018) and Zheng et al. (2018). The soil was taken from the top layer $(0-20 \mathrm{~cm})$ and then sieved with a $2 \mathrm{~mm}$ strainer to remove gravel. The soil was incubated for seven days before incubated with leaves and earthworms. The leaves were dried at $60^{\circ} \mathrm{C}$ for 24 hours, then cut to $2-3 \mathrm{~cm}$ in size and mashed using a blender to pass the $1 \mathrm{~mm}$ filter. The leaves were saturated with distilled water for 24 hours and dried, and its weight was determined to obtain water holding capacity (Hoeffner et al., 2018).

Phretima californica earthworms were collected from the upper slopes of Mount Merapi. Before incubation, the earthworm 's digestive tract was emptied first by placing it on a petri dish covered with moist filter paper for 24 hours (Cesarz et al, 2016; Hoeffner et al., 2018). After the digestive tract was empty (marked by the loss of black particles from the body earthworms), the earthworms were incubated together with the soil and leaves.

\subsection{Incubation and sampling}

This study was carried out using a microcosms system, in which $100 \mathrm{~g}$ of soil, together with $35 \mathrm{~g}$ of leaves litter and 10 earthworms, was incubated in $500 \mathrm{ml}$ plastic tubes. The soil and litter were separated by a wire gauze that has a hole size of $1 \mathrm{~mm}$. The tube was covered with polyethylene cloth and tied with rubber to keep the earthworms from coming out but still to maintain aeration. The experiment consisted of three replications that were stored in an incubator at $25^{\circ} \mathrm{C}$ for 105 days. Leaves sampling was performed at $0,7,15,30,45,75$, and 105 days of incubation.

\subsection{Analysis of soil and leaves litter}

Leaves litter was removed from the plastic tube and separated from earthworms on 0, 7, 15, 30, 45, 75, and 105 days after incubation. Furthermore, leaves litter was dried at $60^{\circ} \mathrm{C}$ for 24 hours and then analyzed chemically. Soil reaction $\left(\mathrm{pH}-\mathrm{H}_{2} \mathrm{O}\right)$ was measured using a $\mathrm{pH}$ meter with a ratio of 1:5 for soil and distilled water (Miller \& Kissel, 2010). The organic $\mathrm{C}$ content of the soil and leaves litter was measured using the muffle furnace method at $550^{\circ} \mathrm{C}$ (Miller \& Kissel, 2010), assuming that organic matter had $58 \% \mathrm{C}$. The total $\mathrm{N}$ content of the soil and leaves litter was measured using the Kjeldahl destruction method (Unckell, 2018), and the C/N ratio was obtained from the calculation. The total nutrient contents of the leaf litter were determined using the wet ashing method by Stammer \& Mallarino (2018), where determining of $K$ and $\mathrm{Na}$ used flame photometry, $\mathrm{Ca}$ and $\mathrm{Mg}$ used Atomic Absorption Spectrophotometry (AAS), and $P$ used spectrophotometry equipment. Lignin and $\alpha$-cellulose of the leaf litter were analyzed using the Klason method (Kirk \& Obst, 1988), while hemicellulose was analyzed using the modified chlorite method (Paloheimo et al., 1962).

\subsection{Nitrogen mineralization}

The leaves litter was incubated with earthworms at $25^{\circ} \mathrm{C}$, and nitrogen mineralization was measured at $0,7,15,30,45$, 75 , and 105 days. Five grams of litter were put in a plastic bottle, then added with a $50 \mathrm{ml} 2 \mathrm{M} \mathrm{KCl}$ solution and shaken for an hour. The solution was filtered with Whatman paper no.42, and the aliquot was analyzed to determine ammonium $\left(\mathrm{NH}_{4}{ }^{+}\right)$content by using the indophenol blue method (Bolleter et al, 1961). Nitrate $\left(\mathrm{NO}_{3}{ }^{-}\right)$was measured using a derivative spectrophotometric method (Lastra, 2003), in which $0.1 \mathrm{~g}$ of the litter passing of 40 mesh strainer was saturated with 10 $\mathrm{ml}$ of distilled water and heated at $45^{\circ} \mathrm{C}$ using a water bath for an hour then filtered using Whatman paper no.42 until clear extract was obtained. As much as $0.1 \mathrm{ml}$ of clear extract was put into a test tube, and $0.4 \mathrm{ml}$ of salicylic acid solution was added and allowed to stand for 20 minutes at room temperature. A total of $9.5 \mathrm{ml}$ of $2 \mathrm{~N} \mathrm{NaOH}$ was added slowly and directly measured using spectrophotometry at a wavelength of $388 \mathrm{~nm}$.

The potential of $\mathrm{N}$ mineralization was calculated by the kinetic approach of the Zero order, First order, and Secondorder models (Stanford \& Smith, 1972). Nitrogen mineralization was $\mathrm{N}$ that was mineralized in time $(\mathrm{t}), \mathrm{N}_{0}$ was the potential for mineralized $\mathrm{N}$, and $\mathrm{k}$ was the rate of mineralization.

Linier equation of Zero order: $[A]_{t}=[A]_{0}+k t \ldots \ldots \ldots \ldots \ldots \ldots . . . \ldots[1]$ Linier equation of First order: $\log [A]_{t}=\log [A]_{0}-(k t / 2.303)$. [2] Linier equation of Second order: $1 /[\mathrm{A}]_{\mathrm{t}}=1 /[\mathrm{A}]_{0}+\mathrm{kt} \ldots \ldots \ldots \ldots[3]$ 
Table 1. Chemical characteristics of perennial leaves litter

\begin{tabular}{lcccc}
\hline \multirow{2}{*}{ Parameters } & \multicolumn{4}{c}{ Perennial Plant Leaves Litter } \\
\cline { 2 - 5 } & Acacia & Coffee & Salacca & Bamboo \\
\hline Total C (\%) & 60.94 & 61.67 & 58.68 & 58.28 \\
Total N (\%) & 2.94 & 1.82 & 2.24 & 2.10 \\
C/N & 20.00 & 34.00 & 26.00 & 27.0 \\
Lignin (\%) & 28.06 & 27.96 & 27.33 & 21.55 \\
Cellulose (\%) & 35.45 & 29.05 & 23.50 & 28.95 \\
Hemicellulose (\%) & 19.85 & 17.15 & 38.30 & 36.80 \\
\hline
\end{tabular}

Table 2. Initial physic-chemical characteristics of soil

\begin{tabular}{ccccccc}
\hline & $\mathrm{pH}-\mathrm{H}_{2} \mathrm{O}$ & Total-N (\%) & Total-C (\%) & $\mathrm{BV}\left(\mathrm{g} \mathrm{cm}^{-3}\right)$ & $\mathrm{C} / \mathrm{N}$ & Texture \\
\hline soil & 6.22 & 0.14 & 8.51 & 2.05 & 60 & sandy \\
\hline
\end{tabular}

Table 3. Two-Way ANOVA on perennial plant leaves with incubation time

\begin{tabular}{lllllllll}
\hline Variable & $\mathbf{N H}_{4}{ }^{+}$ & \multicolumn{1}{c}{} & & $\mathbf{N O}_{3}{ }^{-}$ & & \\
\cline { 2 - 10 } & $\begin{array}{l}\text { Sum of } \\
\text { Square }\end{array}$ & $\begin{array}{l}\text { Mean } \\
\text { Square }\end{array}$ & F-value & Sign. & $\begin{array}{l}\text { Sum of } \\
\text { Square }\end{array}$ & $\begin{array}{l}\text { Mean } \\
\text { Square }\end{array}$ & F-value & Sign. \\
\hline $\mathrm{L}$ & 0.0009 & 0.0003 & 19.20 & $* *$ & 3.23 & 1.07 & 5.11 & $* *$ \\
\hline $\mathrm{T}$ & 0.0008 & 0.0001 & 8.15 & $* *$ & 14.18 & 2.36 & 11.18 & $* *$ \\
\hline $\mathrm{L}^{*} \mathrm{~T}$ & 0.0011 & 0.00006 & 3.61 & $* *$ & 13.24 & 0.73 & 3.48 & $* *$ \\
\hline
\end{tabular}

Remarks: L= Annual Plant Litter; T = Times Incubation; L*T = Interaction of Litter Plant with Incubation time;

Significant $* *=p$-value $<0.01$

\subsection{Chemical properties of the soil and leaves litter}

The chemical properties from acacia, coffee, salacca, and bamboo leaf litter were one of the factors that determine $\mathrm{N}$ mineralization. These properties would be associated with the decomposition process that is assisted by earthworm, where the leaf litter that had high recalcitrant compounds would be arduous decomposition. The initial chemical properties from leaf litter were presented in Table 1.

Total nitrogen content of acacia, coffee, salacca, and bamboo leaf was $2.94 \%, 1.82 \%, 2.24 \%$, and $2.10 \%$, respectively. The acacia leaf had the highest total $\mathrm{N}$ than others. The total carbon of acacia, coffee, salacca, and bamboo leaf was $60.94,61.67,58.68$, and 58.28 , respectively. The coffee leaf had the highest total $\mathrm{C}$ than others. The $\mathrm{C} / \mathrm{N}$ ratio obtained was $20,34,26$, and 27 , where the coffee leaf had the highest $\mathrm{C} / \mathrm{N}$ ratio. The total percentage of lignin from acacia, coffee, salacca, and bamboo leaf was $28.06 \%, 27.96 \%$, $27.33 \%$, and $21.55 \%$, respectively. The total percentage of cellulose from acacia, coffee, salacca, and bamboo leaf was $35.45 \%, 29.05 \%, 23.50 \%$, and $28.95 \%$, respectively. The total percentage of hemicellulose from acacia, coffee, salacca, and bamboo leaf was $19.85 \%, 17.15 \%, 38.3 \%$, and $36.8 \%$, respectively (Table 1 ).

The Physico-chemical properties of the initial soil affect the leaf litter decomposition. The initial characteristics of soil (Table 2) such as actual acidity $\left(\mathrm{pH} \mathrm{H}_{2} \mathrm{O}\right)$ were 6.22 that was classified as slightly acidic. The percentage of organic carbon was $60.94 \%$ and was classified as very high, the percentage of total nitrogen was $0.14 \%$ and was classified as low, $\mathrm{C} / \mathrm{N}$ ratio 60 was classified as high, and a class of texture soil was classified as sandy.

\section{Result}

\subsection{Dynamic release of $\mathrm{NH}_{4}^{+}$and $\mathrm{NO}_{3}^{-}$during incubation}

Statistical evaluation of the significance of leaves litter and time duration of incubation can be done by the analysis of the variance (ANOVA) of the obtained results. The results are summarized in Table 3. The F-values of 19.2 (litter), 8.15 (time duration), and 3.61 (litter*time duration) for $\mathrm{NH}_{4}{ }^{+}$. The $\mathrm{F}-$ values of 5.11 (litter), 11.18 (time duration), and 3.48 (litter*time duration) for $\mathrm{NO}_{3}{ }^{-}$. Based on $\mathrm{F}$-values, the release of $\mathrm{NH}_{4}{ }^{+}$and $\mathrm{NO}_{3}{ }^{-}$was highly correlated with types of leaf litter and time duration of incubation because it significantly affects $\mathrm{N}$ mineralization ( $\mathrm{p}$-value $<0.01$ ).

The release time of $\mathrm{NH}_{4}{ }^{+}$was faster than $\mathrm{NO}_{3}{ }^{-}$. The release of $\mathrm{NH}_{4}{ }^{+}$from acacia showed increasing up to 15 days after incubation and had been highest released. After that, the release showed decreased at 30 days after incubation and increased again for 45 days after incubation. The release of $\mathrm{NH}_{4}{ }^{+}$from coffee showed the highest release was on 15 days after incubation and the lowest was on 30 days after incubation. The release of $\mathrm{NH}_{4}{ }^{+}$from salacca showed the highest release was on 15 days after incubation and the lowest was on 0 days after incubation. The release of $\mathrm{NH}_{4}{ }^{+}$ from bamboo showed the highest release was on 15 days after incubation and the lowest was on 30 days after incubation. The dynamic of release time from $\mathrm{NH}_{4}{ }^{+}$is presented in Figure 1.

The release of $\mathrm{NO}_{3}{ }^{-}$from acacia showed increasing up to 30 days after incubation and had been the highest released. After that, the release showed a decreased on 45 days after incubation and had been the lowest released. The release of $\mathrm{NO}_{3}{ }^{-}$from coffee showed the highest release was on 105 days after incubation and the lowest release was on 0 days after incubation. The release of $\mathrm{NO}_{3}^{-}$from salacca showed increasing up to 105 days after incubation and represented 
this litter had linearly related to duration time. The release started increasing on 45 days after incubation. The highest release was on 105 days after incubation and the lowest release was 30 days after incubation. The release of $\mathrm{NO}_{3}{ }^{-}$from bamboo showed decreasing up to 7 days after incubation and started increasing at 15 days after incubation up to 45 days after incubation. After that, the release showed decreasing up to 75 days after incubation and increasing again up to 105 days after incubation. The highest release was 105 days after incubation. The dynamic of release time from $\mathrm{NO}_{3}{ }^{-}$is presented in Figure 2.
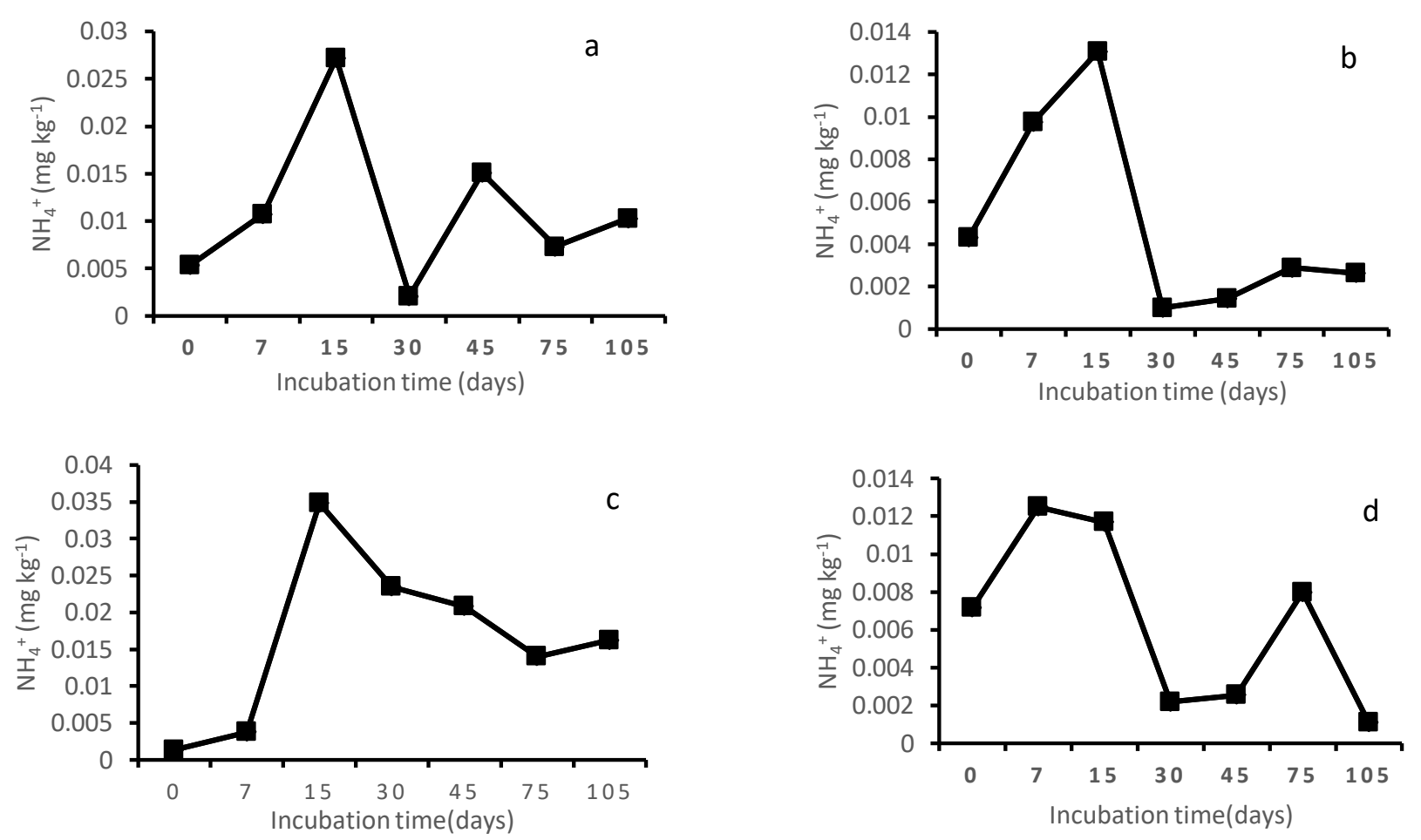

Figure 1. The dynamics mineralization $\mathrm{NH}_{4}{ }^{+}$between different types of leaves litter: (a) acacia, (b) coffee, (c) salacca, and (d) bamboo with $\mathrm{N}$ mineralization dynamics for 105 days
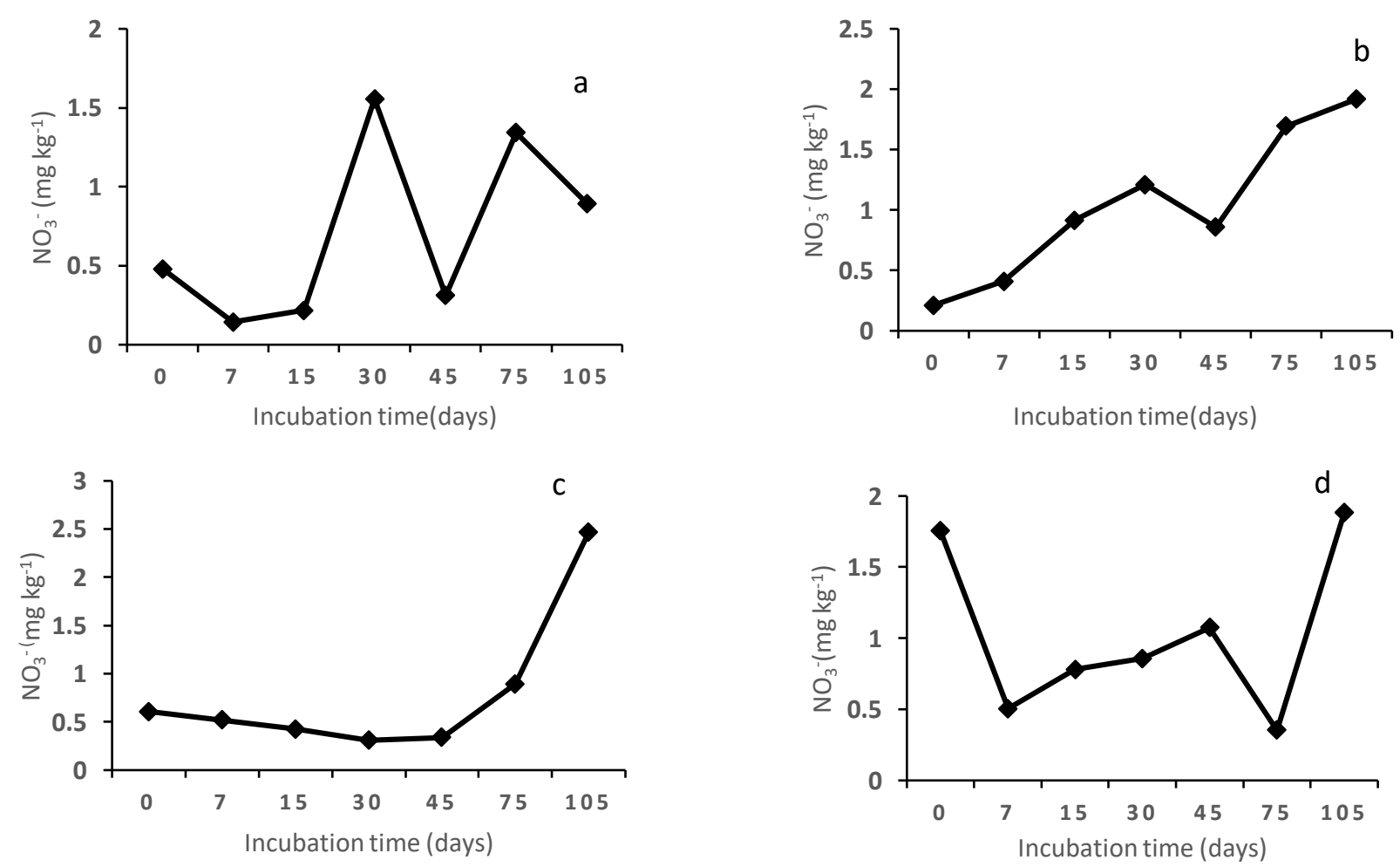

Figure 2. The dynamics mineralization $\mathrm{NO}_{3}{ }^{-}$between different types of leaves litter: (a) acacia, (b) coffee, (c) salacca, and (d) bamboo with $\mathrm{N}$ mineralization dynamics for 105 days 
Table 4. Kinetics of nitrogen mineralization of perennial plant leaves litter

\begin{tabular}{|c|c|c|c|c|c|c|}
\hline \multirow{3}{*}{ Treatments } & \multicolumn{6}{|c|}{ Kinetics Equation Parameters } \\
\hline & \multicolumn{2}{|c|}{ Coef. of Determination $\left(\mathrm{R}^{2}\right)$} & \multicolumn{2}{|c|}{ Mineralization Rate (k) $25^{\circ} \mathrm{C} \mathrm{day}^{-1}$} & \multicolumn{2}{|c|}{ Potential Mineralization $\left(\mathrm{N}_{0}\right) \mathrm{mg} \mathrm{kg}^{-}$} \\
\hline & {$\left[\mathrm{NH}_{4}^{+}\right]$} & {$\left[\mathrm{NO}_{3}{ }^{-}\right]$} & {$\left[\mathrm{NH}_{4}{ }^{+}\right]$} & {$\left[\mathrm{NO}_{3}^{-}\right]$} & {$\left[\mathrm{NH}_{4}^{+}\right]$} & {$\left[\mathrm{NO}_{3}{ }^{-}\right]$} \\
\hline Zero Order & \multicolumn{6}{|c|}{$[\mathrm{A}]_{\mathrm{t}}=[\mathrm{A}]_{0}+\mathrm{kt}$} \\
\hline Acacia & 0.11 & 0.42 & 0.01 & 0.03 & -0.001 & 0.13 \\
\hline Coffee & 0.21 & 0.63 & 0.01 & -0.06 & -0.001 & 0.28 \\
\hline Salacca & 0.33 & 0.39 & 0.01 & 0.05 & 0.002 & 0.27 \\
\hline Bamboo & 0.48 & 0.03 & 0.01 & 0.87 & -0.001 & 0.06 \\
\hline First Order & \multicolumn{6}{|c|}{$\log [\mathrm{A}]_{\mathrm{t}}=\log [\mathrm{A}]_{0}-(\mathrm{kt} / 2.303)$} \\
\hline Acacia & 0.05 & 0.45 & -2.05 & -0.75 & -0.04 & 0.10 \\
\hline Coffee & 0.26 & 0.63 & -2.06 & -0.54 & -0.12 & 0.11 \\
\hline Salacca & 0.47 & 0.19 & -2.35 & -0.37 & 0.09 & 0.07 \\
\hline Bamboo & 0.58 & 0.01 & -1.89 & -0.14 & -0.12 & 0.02 \\
\hline Second Order & \multicolumn{6}{|c|}{$1 /[\mathrm{A}]_{\mathrm{t}}=1 /[\mathrm{A}]_{0}+\mathrm{kt}$} \\
\hline Acacia & 0.01 & 0.04 & 178.94 & 2.08 & 10.36 & -0.12 \\
\hline Coffee & 0.54 & 0.44 & 234.45 & 2.77 & -29.83 & -0.33 \\
\hline Salacca & 0.59 & 0.34 & 6.86 & 4.99 & 69.61 & -0.55 \\
\hline Bamboo & 0.09 & 0.004 & 252.14 & 1.71 & 86.68 & -0.04 \\
\hline
\end{tabular}

Table 5. Mean total biomass of earthworms in each earthworm-treated leaf litter before and after incubation

\begin{tabular}{ccc}
\hline Leaf litter & $\begin{array}{c}\text { Before incubation } \\
(\mathbf{g})\end{array}$ & $\begin{array}{c}\text { After incubation } \\
(\mathbf{g})\end{array}$ \\
\hline Acacia & 3.39 & 1.47 \\
Coffee & 1.85 & 1.85 \\
Salacca & 2.96 & 2.30 \\
bamboo & 2.32 & 0.08 \\
\hline
\end{tabular}

\subsection{Kinetics of nitrogen mineralization}

The equation used to describe the kinetic of $N$ mineralization was zero order, first order, and second order. The coefficient of determination $\left(R^{2}\right)$, mineralization rate $(k)$, and potential $\left(\mathrm{N}_{0}\right)$ were used to determine the mineralization process from leaves litter that was incubated is presented in Table 4.

Zero order model had the $\mathrm{NH}_{4}^{+}$mineralization for acacia, coffee, salacca, and bamboo leaf litter had the coefficient of determination $(0.11,0.21,0.33$, and 0.48 , respectively). The mineralization rate $(k)$ from these leaves litter $\left(0.01\right.$ day $^{-1}$ each other) and potential (-0.001, $-0.001,0.002$, and -0.001 $\mathrm{mg} \mathrm{kg}{ }^{-1}$, respectively). Moreover, the $\mathrm{NO}_{3}{ }^{-}$mineralization for leaves litter each other had the coefficient of determination $(0.42,0.63,0.39$, and 0.03 , respectively). The mineralization rate $\left(0.03,-0.06,0.05\right.$, and 0.87 day $^{-1}$, respectively) and potential $\left(0.13,0.28,0.27\right.$, and $0.06 \mathrm{mg} \mathrm{kg}^{-1}$, respectively).

In the first order model had the $\mathrm{NH}_{4}{ }^{+}$mineralization for acacia, coffee, salacca, and bamboo leaf litter had the coefficient of determination $(0.05,0.26,0.47$, and 0.58 , respectively). The mineralization rate $(-2.05,-2.06,-2.35$, and -1.89 day $^{-1}$, respectively) and potential $(-0.04,-0.12,0.09$, and $-0.12 \mathrm{mg} \mathrm{kg}^{-1}$, respectively). The $\mathrm{NO}_{3}{ }^{-}$mineralization for these leaves litter had the coefficient of determination $(0.45,0.63$, 0.19 , and 0.01 , respectively). The mineralization rate $(-0.75$, $0.54,-0.37$, and -0.14 day $^{-1}$, respectively) and potential $(0.10$, $0.11,0.07$, and $0.02 \mathrm{mg} \mathrm{kg}^{-1}$, respectively). In the second order model, the $\mathrm{NH}_{4}{ }^{+}$mineralization for acacia, coffee, salacca, and bamboo leaf litter had the coefficient of determination (0.01, $0.54,0.59$, and 0.09 , respectively). The mineralization rate
(178.94, 234.45, 6.86, and 252.14 day $^{-1}$, respectively) and potential $(10.36,-29.83,69.61$, and $86.68 \mathrm{mg} \mathrm{kg}$, respectively). The $\mathrm{NO}_{3}{ }^{-}$mineralization for the leaves litter, this model had the coefficient of determination $(0.04,0.44,0.34$, 0.004 , respectively). The mineralization rate $(2.08,2.77,4.99$, and 1.71 day $^{-1}$, respectively) and potential $(-0.12,-0.33,-0.55$, and $-0.04 \mathrm{mg} \mathrm{kg}^{-1}$, respectively).

\subsection{Mean total biomass of earthworm}

The mean total biomass of earthworm in leaves litter of acacia showed decreasing between before and after incubation. The weight of biomass before incubation was 3.39 $\mathrm{g}$ and after incubation was $1.47 \mathrm{~g}$. Coffee leaf litter had mean total biomass of earthworm in before incubation was $1.85 \mathrm{~g}$ and after incubation $1.85 \mathrm{~g}$. Salacca leaf litter had mean total biomass earthworm in before incubation was $2.95 \mathrm{~g}$ and after incubation was $2.30 \mathrm{~g}$. Finally, the bamboo leaf litter showed the mean total biomass of earthworm before incubation was $2.32 \mathrm{~g}$, and after incubation $0.08 \mathrm{~g}$. The mean total biomass of earthworm is presented in Table 5.

\subsection{Mean total nutrients of leaves litter}

$\mathrm{pH}$ from acacia, coffee, salacca, and bamboo leaf was not significantly different from before and after incubation. The total nitrogen showed all litters had a significant difference between before and after incubation.

The total phosphor showed the acacia, coffee, and salacca leaf litters led to a significant difference in before and after incubation, but bamboo leaf litter was not significantly different before and after incubation. The total potassium showed coffee and bamboo leaf litters led to significant differences before and after incubation, meanwhile, acacia and salacca were not significantly different. The total calcium showed coffee and salacca leaf litter led to significant difference on before and after incubation, meanwhile acacia and bamboo were not significantly different. The total magnesium showed all litters were not significantly different before and after incubation. The mean total nutrients from leaves litter incubation are presented in Table 6. 
SAINS TANAH - Journal of Soil Science and Agroclimatology, 17(2), 2020, 152-160

Table 6. Mean total nutrients of leaf litters before and after incubation

\begin{tabular}{|c|c|c|c|c|c|c|c|c|}
\hline \multirow{2}{*}{ Analysis } & \multicolumn{4}{|c|}{ Before incubation } & \multicolumn{4}{|c|}{ After incubation } \\
\hline & Acacia & Coffee & Salacca & Bamboo & Acacia & Coffee & Salacca & Bamboo \\
\hline $\mathrm{pH}$ & $5.68^{b c d}$ & $6.57^{a b c}$ & $5.25^{\mathrm{cd}}$ & $6.31^{\mathrm{abcd}}$ & $6.90^{\mathrm{ab}}$ & $7.46^{a}$ & $5.13^{d}$ & $6.66^{\mathrm{ab}}$ \\
\hline $\mathrm{N}(\%)$ & $11.00^{\mathrm{a}}$ & $7.15^{b}$ & $0.84^{c}$ & $2.04^{c}$ & $1.97^{c}$ & $1.19^{c}$ & $1.05^{c}$ & $0.63^{c}$ \\
\hline $\mathrm{P}(\%)$ & $0.0002^{b c}$ & $0.0002^{c}$ & $0.0003^{b c}$ & $0.002^{\mathrm{abc}}$ & $0.005^{a}$ & $0.004^{\mathrm{ab}}$ & $0.005^{a}$ & $0.004^{a b c}$ \\
\hline K (\%) & $5.51^{c}$ & $8.67^{a}$ & $7.49^{\mathrm{ab}}$ & $3.82^{d}$ & $5.18^{c}$ & $6.29^{b c}$ & $5.17^{\mathrm{ab}}$ & $5.84^{c}$ \\
\hline $\mathrm{Ca}(\%)$ & $0.008^{b c}$ & $0.009^{b}$ & $0.008^{c}$ & $0.008^{c}$ & $0.009^{b}$ & $0.01^{\mathrm{a}}$ & $0.009^{b}$ & $0.008^{b c}$ \\
\hline $\operatorname{Mg}(\%)$ & $0.050^{\mathrm{bc}}$ & $0.054^{\mathrm{ab}}$ & $0.056^{\mathrm{ab}}$ & $0.049^{c}$ & $0.051^{\mathrm{abc}}$ & $0.055^{\mathrm{ab}}$ & $0.059^{a}$ & $0.049^{b c}$ \\
\hline
\end{tabular}

Remarks: The values with the same letter are not significantly different at $p<0.05$

Some macronutrients from acacia leaf litter during the decomposition process (Table 6 ) showed high total $\mathrm{N}$ and $\mathrm{K}$ nutrients, but low total $\mathrm{P}, \mathrm{Ca}$, and $\mathrm{Mg}$. The number of $\mathrm{P}, \mathrm{Ca}$, and $\mathrm{Mg}$ nutrients after incubation were $0.005 \%, 0.009 \%$, and $0.051 \%$, respectively. For coffee, The $\mathrm{P}, \mathrm{Ca}$, and $\mathrm{Mg}$ nutrients at the end of incubation were $0.004 \%, 0.01 \%$, and $0.05 \%$, respectively. For salacca, Nitrogen content was likely to promote mobilization of phosphorus, which was supported by the increase in phosphatase activity. Macronutrients like $\mathrm{P}, \mathrm{Ca}$, and $\mathrm{Mg}$ nutrient were $0.005 \%, 0.009 \%$, and $0.059 \%$, respectively. And the last for bamboo, Total $\mathrm{P}, \mathrm{Ca}$, and $\mathrm{Mg}$ at the end of incubation were $0.004 \%, 0.008 \%$, and $0.049 \%$, respectively.

\section{Discussion}

Among the three kinetic models for $\mathrm{NH}_{4}{ }^{+}$mineralization, the second-order model performed the highest coefficient determination for coffee and salacca leaves litter. The high $\mathrm{NH}_{4}{ }^{+}$mineralization rate can be seen in Figure 1, where the highest release was about 15 days incubation and decreased to 105 days. The greatest mineralization occurred at 15 days that be expected because of the high percentage of recalcitrant compounds in both of the leaves litter. These results are in line with Mishra et al. (2016) where a significant increase in nitrogen mineralization was observed after 15 days up to 45 days of incubation in comparison to the initial day. After 90 days it reached its initial level. The slow rate of $\mathrm{N}$ mineralization may be due to the slow decomposition of organic matter because of the presence of higher molecular weight compounds such as lignin and cellulose. The characteristics of salacca and coffee leaf litter (Table 1) that also contribute to $\mathrm{N}$ mineralization, where the salacca leaf litter has the highest hemicellulose and coffee leaf litter has the highest total carbon and $\mathrm{C} / \mathrm{N}$ ratio and the lowest total nitrogen content. The high compound of hemicellulose for salacca can be stimulated mineralization on the initial stage of decomposition and decreased after that. Moreover, Cavatte et al. (2012) adding state that plants that have high concentrations of secondary metabolites, such as phenol compounds that are rich in carbon will be lead to low decomposition in the latter stage. The coffee leaf litter has a high potassium content (Table 6) as said by Menegatti et al. (2014) where the coffee residue had a higher concentration of $\mathrm{K}$ but didn 't affect decomposition. $\mathrm{K}$ did not any structural function in plants and because it's not incorporated into any carbon chain, $\mathrm{K}$ can readily return to the soil in a plantavailable form after harvested or plant senescence without decomposition processing. The slope of mineralization in the latter incubation apparently in line with total biomass earthworm that didn't increase throughout incubation time (Table 5). As said by Römbke et al. (2009) that the decrease in earthworm abundance and biomass are probably caused by changes in the chemical composition of the residues and soil organic matter available as food.

The high $\mathrm{NO}_{3}{ }^{-}$mineralization rate of coffee can be seen in Figure 2, where the highest release was about 105 days after incubation. Although they have maximum mineralization at 105 days, coffee leaf litter has faster mineralization than salacca. The coffee starts to increase from 0 days, but salacca starts from 75 days after incubation. Although much not different, the coffee leaf litter has higher total carbon and $\mathrm{C} / \mathrm{N}$ ratio (Table 1) than salacca. However, the total biomass earthworm is not increasing in the latter incubation (Table 5). This is showed that the high $\mathrm{C} / \mathrm{N}$ ratio can be an obstacle for earthworm growth. This is in line with Jiang et al. (2018) where no significant difference in earthworm was detected for the low-quality residue (high $\mathrm{C} / \mathrm{N}$ ratio) treatments until 60 days incubation. The highest $\mathrm{pH}$ in the coffee residue (Table 6) is expected since the degradation process increases the $\mathrm{pH}$ of the organic material and $\mathrm{P}$ release at the initial stage of decomposition (Han et al., 2011). Morrill \& Dawson (1961) add that nitrification is closely related to the $\mathrm{pH}$ reaction, in which ammonium oxidation results in neutral to higher $\mathrm{pH}$, while the oxidation of nitrite to nitrate leads to $\mathrm{pH}$ value below the neutral point. Moreover, Abdelhafez et al. (2018) also state that increased acidity is caused by the decomposition of organic matter, which is due to the release of $\mathrm{H}$ ions together with nitrification that occurred in the respiration of decomposer organisms under aerobic conditions. The coffee leaf litter has the lowest $\mathrm{P}, \mathrm{Ca}$, and $\mathrm{Mg}$ nutrient (Table 6) and this is in line with Martinez et al. (2003) where the recommendation for coffee tree nutritional status evaluation is picked of leaf samples that take place after flowering. In the pre-and post-flowering stages, nutrient absorption is efficient. The mean of $\mathrm{P}, \mathrm{Ca}$, and $\mathrm{Mg}$ nutrients were 1.1, 15.2, and 3.0, respectively, and this result is higher than the report. In leaves, lower concentration occurs at the stage when the fruit is small and increases with growth (Dubberstein et al., 2016). The amount of P nutrient in salacca is lower than the result of Adelina et al. (2018) where the mean of $P$ nutrient is $0.20 \%$. Lower P might be caused by the leaf sample that was used for analysis came from the oldest leaf. Adelina et al. (2018) stated that phosphorus is easily redistributed from one organ to another, easily dissipated from older leaves, and accumulates in younger leaves. The utilization of dead leaves for decomposition gives important 
information about the functional state of the perennial plants and the data can be used to evaluate the possibility of using litterfall nutrient content as an index to tree nutrition (Robert et al., 1996).

The first-order model has the highest coefficient of determination from bamboo. The high $\mathrm{NH}_{4}^{+}$mineralization rate can be seen in Figure 1, where the highest release is about 7 to 15 days after incubation. After that, mineralization decreases at 30 to 45 days and increases again at 75 days, and finally decreases until 105 days. The highest mineralization occurred at 7 to 15 days (initial decomposition) probably caused by the $\mathrm{C} / \mathrm{N}$ ratio that has been by this litter (Table 1 ). This result is in line with Marinari et al. (2010) where the $\mathrm{C} / \mathrm{N}$ ratio is positively correlated to the potential mineralization of $\mathrm{NH}_{4}{ }^{+}$in an organic matter because it is more easily decomposed. The decrease at 15 to 30 days is likely caused by competition between lignin and cellulose decomposer and increasing for 75 days probably despite by decomposition of other $\mathrm{C}$ forms like hemicellulose and soluble $\mathrm{C}$. This result is in line with Talbot \& Treseder (2012) where the fluctuation of mineralization is caused by the activity of decomposers while decomposed lignin and cellulose and occurred competition in both of them. After that, the presence of other $\mathrm{C}$ forms (hemicellulose and soluble $\mathrm{C}$ ) that have not degraded, lead to increasing mineralization on the next level incubation. The litter that high has $\mathrm{N}$ compounds induces $\mathrm{C}$ limitation of decomposed activity. Furthermore, the illustration of $\mathrm{NO}_{3}$ mineralization rate can be seen in Figure 2, where the highest released for $\mathrm{NO}_{3}{ }^{-}$is 105 days after incubation. On this figure, $\mathrm{NO}_{3}{ }^{-}$mineralization increased from 7 to 45 days after incubation and decreased at 75 days. This result is in line with Masunga et al. (2016) where the net $N$ mineralization increased at the beginning of the incubation period that was recorded at 40 days of incubation. This is probably caused by sufficient $\mathrm{N}$ to degradation activity. After that, the mineralization is slowed and stopped at 75 days probably caused by the organic $\mathrm{N}$ is complexed in the more stable recalcitrant compounds that remained after the initial rapid mineralization. After 75 days of incubation, the mineralization increased to 105 days, because lignin compounds can control decomposers for degradation of organic material. When lignin degradation occurred, $\mathrm{N}$ released from the cell wall and the microbes break down lignin to access protected $\mathrm{N}$ particularly (Talbot \& Treseder, 2012). The macronutrients from bamboo leaf litter have lower $\mathrm{N}$ and $\mathrm{P}$ nutrients than the result from Tu et al. (2011) that showed bamboo leaf had total $\mathrm{N}$ and $\mathrm{P}$ were 3.88 and $0.35 \mathrm{~g} \mathrm{~kg}^{-1}$, respectively. It might be caused there were different structures domination tree species and physical structure between them. The plantation dominated by a single tree species, they found that the chemical differences (also some physical structure differences) between litter fractions can lead to different mass loss patterns.

Acacia leaf litter had the highest $\mathrm{N}$ mineralization in the zero-order model. The high $\mathrm{NH}_{4}^{+}$mineralization can be seen in Figure 1, where the highest release is about 15 days after incubation. After 15 days, the release decreased at 30 days and increase again at 45 days and decreased to 105 days. The characteristic of acacia leaf litter (Table 1) may be a reason for this trend, where this litter had the highest lignin (28.06\%), cellulose (35.45\%), and total nitrogen (2.94\%). The high $\mathrm{N}$ compound in this litter produces rapid mineralization in initial decomposition. This result was in line with Pei et al. (2019) were at the earlier stage, the leaching loss of soluble compounds is the dominant process for the litter with more easily degradable components (usually higher initial $\mathrm{N}$ ) and then the mineralization becomes very slow due to lignified materials and lipids. The high $\mathrm{NO}_{3}{ }^{-}$mineralization rate can be seen in Figure 2, where the highest release was about 30 days. At 30 days occurred the highest $\mathrm{NO}_{3}{ }^{-}$release was at the same time occurred the lowest $\mathrm{NH}_{4}{ }^{+}$release and the second release $\mathrm{NO}_{3}{ }^{-}$at 45 days while the second decrease in $\mathrm{NH}_{4}{ }^{+}$at the same time. Mineralization $\mathrm{NH}_{4}{ }^{+}$and $\mathrm{NO}_{3}{ }^{-}$occurred in reverse. This result is in line with Azam et al. (1993) where the nitrification of $\mathrm{NH}_{4}{ }^{+}-\mathrm{N}$ was slowed in the presence of $\mathrm{NO}_{3}{ }^{-}$because $\mathrm{NH}_{4}{ }^{+}$ was immobilized in preference to $\mathrm{NO}_{3}^{-}$, this inhibitory effect may have contributed to the difference between $\mathrm{NH}_{4}{ }^{+}$and $\mathrm{NO}_{3}{ }^{-}$in promoting the mineralization $\mathrm{N}$. Total nitrogen and phosphor acacia have different significance between before and after incubation (Table 6). The lowest value at latter incubation is in line with the results from Abdulrazak et al. (2000) and Rubanza et al. (2007) where the amount of P, Ca, and $\mathrm{Mg}$ nutrient from acacia tree leaves were 0.9-4.1, 8.822.4 , and $2.2-2.3 \mathrm{~g} \mathrm{~kg}^{-1}$, respectively. The lowest nutrients might be caused by the treatment different from a sample that will be analyzed. In this research, the acacia leaf is collected from the plant that has fallen. Meanwhile, according to the research from Abdulrazak et al. (2000) and Rubanza et al. (2007) that the leaf samples are harvested at their advanced maturity stage at the end of the rainy seasons and then pooled and oven-dried at $60^{\circ} \mathrm{C}$ for 48 hours.

Among 7 to 15 days incubation (Figure 2), the release of $\mathrm{NO}_{3}{ }^{-}$in acacia and bamboo leaf litters underwent relatively high fluctuations, whereas for coffee and salacca leaf litters tended to be linear. The potential mineralization $\left(\mathrm{N}_{0}\right)$ that is lower than the mineralization rate $(\mathrm{k})$ is acacia $\left(\mathrm{NH}_{4}{ }^{+}\right.$ mineralization), salacca $\left(\mathrm{NO}_{3}{ }^{-}\right.$mineralization), and coffee $\left(\mathrm{NH}_{4}^{+}\right.$and $\mathrm{NO}_{3}^{-}$mineralization). Moreover, the potential mineralization that is higher than the mineralization rate is salacca $\left(\mathrm{NH}_{4}{ }^{+}\right.$mineralization), acacia ( $\mathrm{NO}_{3}{ }^{-}$mineralization), and bamboo $\left(\mathrm{NH}_{4}{ }^{+}\right.$and $\mathrm{NO}_{3}{ }^{-}$mineralization). The reason for this condition was associated with variable $\mathrm{N}$ immobilized. This result was in line with Guendehou et al. (2014) where the high differences in the initial litter quality (carbon and nitrogen) across the species contributed to absolute decay rates (k), ranging from 1.69-4.67 year ${ }^{-1}$. The higher $k$ values represented a larger amount of readily decomposable organic matter (Purwanto et al., 2005). The same thing was stated by Toda \& Haibara (1999), that the low $k$ value in cedar and cypress trees illustrates that $\mathrm{N}$ mineralization was affected not only by total $\mathrm{N}$ in residue but also in total carbon used for $\mathrm{N}$ release. The low $\mathrm{k}$ value from the decomposition of plant litter is correlated with reducing total biomass earthworm (Table 5), where Dechaine et al. (2005) adding state that reducing earthworm numbers in tropical soil decreased the decomposition rate of plant litter. 


\section{Conclusion}

Different types and chemical composition of the litter led to different $\mathrm{N}$ mineralization and kinetic models. The kinetic model of zero-order and the first-order was able to describe the release of $\mathrm{NH}_{4}{ }^{+}$in bamboo and $\mathrm{NO}_{3}{ }^{-}$release in coffee and the second-order was able to describe $\mathrm{NH}_{4}{ }^{+}$mineralization of salacca leaf. Kinetics of $\mathrm{N}$ mineralization can be a strategy for the use of perennial plant leaves litter as a source of nutrient input for maintaining soil health and fertility.

\section{Declaration of Competing Interest}

The authors declare no competing financial or personal interests that may appear and influence the work reported in this paper.

\section{References}

Abdelhafez, A. A., Abbas, M. H. H., Attia, T. M. S., El Bably, W., \& Mahrous, S. E. (2018). Mineralization of organic carbon and nitrogen in semi-arid soils under organic and inorganic fertilization. Environmental Technology and Innovation, 9, 243-253. https://doi.org/10.1016/j.eti.2017.12.011

Abdulrazak, S. A., Fujihara, T., Ondiek, J. K., \& Ørskov, E. R. (2000). Nutritive evaluation of some Acacia tree leaves from Kenya. Animal Feed Science and Technology, 85(12), 89-98. https://doi.org/10.1016/S03778401(00)00133-4

Adelina, R., Suliansyah, I., \& Syarief, A. (2018). Evaluation Nutrients Content in Salak Sidimpuan Leaves (Salacca sumatrana Becc .). 6(5), 3-7.

Azam, F., Simmons, F. W., \& Mulvaney, R. L. (1993). Immobilization of ammonium and nitrate and their interaction with native $\mathrm{N}$ in three Illinois Mollisols. Biology and Fertility of Soils, 15(1), 50-54. https://doi.org/10.1007/BF00336288

Bhat, Z.S., Saroa, G.S., Benbi, D.K., Choudary, O.P., \& Padder, S. A. (2018). Nitrogen Mineralization Kinetics in Soils Incubated At Different Nitrogen Mineralization Kinetics in Soils Incubated At Different Temperatures Amended With Organic and. November.

Bolleter, W. T., Bushman, C. J., \& Tidwell, P. W. (1961). Spectrophotometric Determination of Ammonia as Indophenol. Analytical Chemistry, 33(4), 592-594. https://doi.org/10.1021/ac60172a034

Cavatte, P. C., Rodríguez-López, N. F., Martins, S. C. V., Mattos, M. S., Sanglard, L. M. V. P., \& Damatta, F. M. (2012). Functional analysis of the relative growth rate, chemical composition, construction and maintenance costs, and the payback time of Coffea arabica L. leaves in response to light and water availability. Journal of Experimental Botany, 63(8), 3071-3082. https://doi.org/10.1093/jxb/ers027

Cesarz, S., Craven, D., Dietrich, C., \& Eisenhauer, N. (2016). Effects of soil and leaf litter quality on the biomass of two endogeic earthworm species. European Journal of Soil Biology, 77, 9-16. https://doi.org/10.1016/j.ejsobi.2016.09.002
Dechaine, J., Ruan, H., Sanchez-De Leon, Y., \& Zou, X. (2005). Correlation between earthworms and plant litter decomposition in a tropical wet forest of Puerto Rico. Pedobiologia, 49(6), 601-607. https://doi.org/10.1016/j.pedobi.2005.07.006

Dubberstein, D., Partelli, F. L., Dias, J. R. M., \& Espindola, M. C. (2016). Concentration and accumulation of macronutrients in the leaf of coffee berries in the Amazon, Brazil. Australian Journal of Crop Science, 10(5), 701-710.

https://doi.org/10.21475/ajcs.2016.10.05.p7424

Guendehou, G. H. S., Liski, J., Tuomi, M., Moudachirou, M., Sinsin, B., \& Mäkipää, R. (2014). Decomposition and changes in the chemical composition of leaf litter of five dominant tree species in a West African tropical forest. Tropical Ecology, 55(2), 207-220.

Han, M. Y., Zhang, L. X., Fan, C. H., Liu, L. H., Zhang, L. S., Li, B. Z., \& Alva, A. K. (2011). Release of nitrogen, phosphorus, and potassium during the decomposition of apple (Malus Domestica) leaf litter under different fertilization regimes in Loess Plateau, China. Soil Science and Plant Nutrition, 57(4), 549-557. https://doi.org/10.1080/00380768.2011.593481

Hasegawa, T., \& Horie, T. (1994). A Simplified Model for Estimating Nitrogen Mineralization in Paddy Soil. Jpn. J. Crop Sci, 3(63), 496-501.

Hoeffner, K., Monard, C., Santonja, M., \& Cluzeau, D. (2018). Feeding behaviour of epi-anecic earthworm species and their impacts on soil microbial communities. Soil Biology and Biochemistry, 125(July), 1-9. https://doi.org/10.1016/j.soilbio.2018.06.017

Jiang, Y., Wang, J., Muhammad, S., Zhou, A., Hao, R., \& Wu, Y. (2018). How do earthworms affect decomposition of residues with different quality apart from fragmentation and incorporation? Geoderma, 326(April), 68-75. https://doi.org/10.1016/j.geoderma.2018.04.013

Kernecker, M., Whalen, J. K., \& Bradley, R. L. (2014). Litter Controls Earthworm-Mediated Carbon and Nitrogen Transformations in Soil from Temperate Riparian Buffers. Applied and Environmental Soil Science, 2014(3). https://doi.org/10.1155/2014/329031

Kirk, T. K., \& Obst, J. R. (1988). Lignin determination. Methods in Enzymology, 161(C), 87-101. https://doi.org/10.1016/0076-6879(88)61014-7

Lastra, O. C. (2003). Derivative spectrophotometric determination of nitrate in plant tissue. Journal of $A O A C$ International, 86, 1101-1105.

Lodhi, A., Arshad, M., Azam, F., \& Sajjad, M. H. (2009). Changes in mineral and mineralizable $\mathrm{N}$ of soil incubated at varying salinity, moisture, and temperature regimes. Pakistan Journal of Botany, 41(2), 967-980.

Lubbers, I. M., Pulleman, M. M., \& Van Groenigen, J. W. (2017). Can earthworms simultaneously enhance decomposition and stabilization of plant residue carbon? Soil Biology and Biochemistry, 105, 12-24. https://doi.org/10.1016/j.soilbio.2016.11.008

Manzoni, S., Jackson, R. B., Trofymow, J. A., \& Porporato, A. (2008). The global stoichiometry of litter nitrogen mineralization. Science, 321(5889), 684-686. 
https://doi.org/10.1126/science.1159792

Marinari, S., Lagomarsino, A., Moscatelli, M. C., Di Tizio, A., \& Campiglia, E. (2010). Soil carbon and nitrogen mineralization kinetics in organic and conventional three-year cropping systems. Soil and Tillage Research, 109(2), https://doi.org/10.1016/j.still.2010.06.002

Martinez, H. E. P., Souza, R. B., Abadía Bayona, J., Alvarez Venegas, V. H., \& Sanz, M. (2003). Coffee-tree floral analysis as a means of nutritional diagnosis. Journal of Plant Nutrition, 26(7), 1467-1482. https://doi.org/10.1081/PLN-120021055

Masunga, R. H., Uzokwe, V. N., Mlay, P. D., Odeh, I., Singh, A., Buchan, D., \& De Neve, S. (2016). Nitrogen mineralization dynamics of different valuable organic amendments commonly used in agriculture. Applied Soil Ecology, 101, 185-193. https://doi.org/10.1016/j.apsoil.2016.01.006

Menegatti, S., Chad, Z., Antonio, C., Alexandre, R., \& Alves, R. (2014). Coffee processing residues as a soil potassium amendment. Int J Recycl Org Waste Agricult, 3, 155-165. https://doi.org/10.1007/s40093-014-0078-7

Miller, R. O., \& Kissel, D. E. (2010). Comparison of soil pH methods on soils of North America. Soil Science Society of America Journal, 74(1), 310-316. https://doi.org/10.2136/sssaj2008.0047

Mishra, A., Kumar, N., Kumar, R., Kumar, R., \& Tomar, D. (2016). Mineralization of carbon, nitrogen, phosphorus, and sulfur from different organic wastes in silty clay loam soils. Journal of Applied and Natural Science, 8(1), 16-22. https://doi.org/10.31018/jans.v8i1.738

Morrill, L. G., \& Dawson, J. E. (1961). Growth Rates of Nitrifying Chemoautotrophs in Soil. J. Bacteriol, 83, 206.

Paloheimo, L., Herkola, E., \& Kero, M.-L. (1962). A method for cellulose determination. Agricultural and Food Science, 34(1), 57-65. https://doi.org/10.23986/afsci.71590

Parton, W., Silver, W. L., Burke, I. C., Grassens, L., Harmon, M. E., Currie, W. S., King, J. Y., Adair, E. C., Brandt, L. A., Hart, S. C., \& Fasth, B. (2007). Global-scale similarities in nitrogen release patterns during long-term decomposition. Science, 315(5810), 361-364. https://doi.org/10.1126/science.1134853

Patti, P. S., Kaya, E., \& Silahooy, C. (2013). Analisis Status Nitrogen Tanah dalam Kaitannya dengan Serapan. Agrologia, 2(1), 78-79.

Pei, G., Liu, J., Peng, B., Gao, D., Wang, C., Dai, W., Jiang, P., \& Bai, E. (2019). Nitrogen, lignin, $C / N$ as important regulators of gross nitrogen release and immobilization during litter decomposition in a temperate forest ecosystem. Forest Ecology and Management, 440(March), 61-69. https://doi.org/10.1016/j.foreco.2019.03.001

Purwanto, B. H., Watanabe, A., Shoon, J. F., Kakuda, K. Ichi, \&
Ando, H. (2005). Kinetic Parameters of Gross N Mineralization of Peat Soils as Related to the Composition of Soil Organic Matter. Soil Science and Plant Nutrition, 51(1), 109-115. https://doi.org/10.1111/j.1747-0765.2005.tb00013.x

Robert, B., Caritat, A., Bertoni, G., Vilar, L., \& Molinas, M. (1996). Nutrient content and seasonal fluctuations in the leaf component of cork-oak (Quercus suber L.) litterfall. Vegetatio, 122(1), 29-35. https://doi.org/10.1007/BF00052813

Römbke, J., Schmidt, P., \& Höfer, H. (2009). The earthworm fauna of regenerating forests and anthropogenic habitats in the coastal region of Paraná. Pesquisa Agropecuária Brasileira, 44(8), 1040-1049. https://doi.org/10.1590/s0100-204×2009000800037

Rubanza, C. D. K., Shem, M. N., Bakengesa, S. S., Ichinohe, T., \& Fujihara, T. (2007). The content of protein, fibre, and minerals of leaves of selected Acacia species indigenous to north-western Tanzania. Archives of Animal Nutrition, 61(2), https://doi.org/10.1080/17450390701203907

Stammer, A. J., \& Mallarino, A. P. (2018). Plant Tissue Analysis to Assess Phosphorus and Potassium Nutritional Status of Corn and Soybean. Soil Science Society of America Journal, 82(1), 260-270. https://doi.org/10.2136/sssaj2017.06.0179

Stanford, G., \& Smith, S. J. (1972). Nitrogen Mineralization Potentials of Soils. Soil Sci. Soc. Amer. Proc, 36, 465-472.

Talbot, J.M., \& Treseder, K. K. (2012). Interactions among lignin, cellulose, and nitrogen drive litter chemistry decay relationships. 93(2), 345-354.

Toda, H. \& K. H. (1999). Effects of carbon properties on characteristics of nitrogen mineralization in forest soil of Kanto region, Japan. Jpn.J.For.Environment, 2, 59-66.

Tu, L. H., Hu, H. L., Hu, T. X., Zhang, J., Liu, L., Li, R. H., Dai, H. Z., \& Luo, S. H. (2011). Decomposition of different litter fractions in a subtropical bamboo ecosystem as affected by experimental nitrogen deposition. Pedosphere, 21(6), 685-695. https://doi.org/10.1016/S10020160(11)60171-9

Unckell, F. (2018). PanReac ApplichChem its Reagents. Determination by Kjeldahl Method Nitrogen Determination by Kjeldahl Method. Retrieved on 21/6/2018. 1-12. https://doi.org/https://www.itwreagents.com/uploads /20180114/A173_EN.pdf

Zheng, Y., Wang, S., Bonkowski, M., Chen, X., Griffiths, B., Hu, F., \& Liu, M. (2018). Litter chemistry influences earthworm effects on soil carbon loss and microbial carbon acquisition. Soil Biology and Biochemistry, 123(September 2017), 105-114. https://doi.org/10.1016/j.soilbio.2018.05.012 